\title{
Abhandlung
}

Serena Sabatini*

\section{Modelling Bronze Age sheepherding and wool production: the case of the Terramara settlement at Montale, Italy}

https://doi.org/10.1515/pz-2020-0005

Zusammenfassung: Um eine ganzheitliche Woll-TextilWirtschaft während der Bronzezeit nachzuweisen, werden in dieser Arbeit Charakteristika und Ausmaß der Weidewirtschaft und der Schafhaltung in der Terramare-Siedlung von Montale (Provinz Modena, Italien) bewertet. Frühere Studien konnten zeigen, dass Montale in der Bronzezeit ein Zentrum der Wollproduktion war. Die vorliegende Arbeit erlaubt ein tieferes Verständnis der lokalen Textilwirtschaft durch die Untersuchung von Nachweisen zur Schäferei und dem örtlichen Landschaftsmanagement. Fernerhin wird ein interdisziplinäres Konzept zur Untersuchung und Rekonstruktion pastoraler Ökonomien und Strategien der Schäferei auch für andere prähistorische Kontexte vorgeschlagen.

Schlüsselworte: Weidewirtschaft, Landschaftspflege, Dichte und Größe der Tierpopulationen, Pastoralismus, Archäozoologie, Archäobotanik

Résumé: Cette contribution examine les caractéristiques et l'étendue de l'économie pastorale du site de Montale, dans la province de Modène. Des études récentes sur les matériaux archéologiques et archéozoologiques du site suggèrent que le village de Montale était un centre important de production de laine à l'âge du Bronze moyen et récent. Le but de ce travail est de mieux comprendre le fonctionnement de l'économie textile locale en analysant les indicateurs de l'activité pastorale et de la gestion des terres. Enfin, l'article propose une méthode interdisciplinaire pour l'étude et la reconstruction du pastoralisme dans des contextes protohistoriques.

Mots clés: économie pastorale, gestion des terres, densité et taille de la population animale, pastoralisme, archéozoologie, archéobotanique

*Corresponding author: Serena Sabatini, Department of Historical Studies, University of Gothenburg, Box 200, 40530 Göteborg,

Sweden. E-Mail: serena.sabatini@archaeology.gu.se
Abstract: Arguing for an integrated wool-textile economy in the Bronze Age, this paper assesses characteristics and scale of pastoral economy and sheepherding at the Terramare settlement of Montale (Modena province, Italy). Previous studies argued that Montale was a Bronze Age centre of wool production. The present work enhances the understanding of the local textile economy by investigating the evidence for sheepherding and landscape management at the site. It also proposes an interdisciplinary-based approach to investigate and reconstruct pastoral economy and sheepherding strategies in other prehistoric contexts as well.

Keywords: Pastoral economy, landscape management, animal population density and size, husbandry practices, archaeozoology, archaeobotany

Riassunto: Il presente contributo propone lo studio delle caratteristiche e dell'entità dell'economia pastorale nel sito terramaricolo di Montale, in provincia di Modena. Recenti studi del materiale archeologico e acheozoologico proveniente dal sito hanno permesso di proporre che l'abitato di Montale fosse un eminente centro di produzione della lana durante l'età del bronzo media e recente. In questo lavoro si vuole approfondire l'argomento attraverso l'analisi degli indicatori di attività pastorale e di gestione del territorio. L'articolo propone, infine, un metodo di carattere interdisciplinare per lo studio e la ricostruzione della pastorizia in ambito protostorico.

Parole chiave: Economia pastorale, gestione del territorio, densità e dimensione della popolazione animale, pastorizia, archeozoologia, archeobotanica

\section{Introduction}

Arguing for an integrated wool-textile economy in the Bronze Age, this paper assesses characteristics and scale of pastoral economy and sheepherding at the Terramare 
settlement of Montale on the Po plain in northern Italy. Previous studies argued that Montale was a Bronze Age centre of wool production ${ }^{1}$. Archaeological evidence from the site in support of this argument includes the astonishing number of textile tools, in particular spindle whorls, but also loom weights ${ }^{2}$. Large numbers of sheep/goat bones among the faunal remains ${ }^{3}$ suggest that wool was the primary fibre for textile manufacture. The present work enhances the understanding of the local textile economy by investigating the evidence for sheepherding at the site. This paper also proposes an interdisciplinary-based approach to investigate and reconstruct characteristics and scale of pastoral economy and sheepherding strategies in other prehistoric contexts as well.

\section{Wool in the Bronze Age}

From the $2^{\text {nd }}$ millennium BC, the introduction of wool and of woollen textile production represented in all likelihood a major innovation in Bronze Age Europe. Archaeological and written evidence show that wool became appreciated and used during the $4^{\text {th }}$ millennium in the Near Eastern region ${ }^{4}$. Archival documents from Mesopotamia, Anatolia, and the Aegean dated to the $3^{\text {rd }}$ and $2^{\text {nd }}$ millennium BC describe that wool and woollen textile production was a complex, but highly rewarding economic activity 5 . Lacking written sources in Europe, the combined interdisciplinary study of archaeological and faunal remains can help us understand the role of wool and woollen textiles ${ }^{6}$.

In recent years, the concept of wool economy has emerged in Bronze Age studies ${ }^{7}$ to underline that engagement with the long chain of essential wool manufacturing processes ${ }^{8}$, would require - to be economically

1 Kristiansen 2016; Sabatini 2018; Sabatini et al. 2018a.

2 Sabatini et al. 2018a; Sabatini 2019.

3 De Grossi Mazzorin/Ruggini 2009.

4 Barber 1991, 24-25.

5 Breniquet/Michel 2014; Michel/Nosch 2010; Nosch 2015; Waetzold 1972; Wright 2013.

6 See Sabatini 2018; Sabatini/Bergerbrant 2019. Extensive archaeological studies have so far shown the widespread use of wool primarily by cataloguing textile fragments from across Europe (Bazzanella 2012; Bender Jørgensen 1992; Bender Jørgensen/Grömer 2013; Bender Jørgensen/Rast-Eicher 2015; Broholm/Hald 1940; CinBA database; Gleba 2008, 43-45, 2014; Gleba/Mannering 2012; Grömer 2013; 2016; Grömer et al. 2013, 2018; Harding 1995; Marić Baković/Car 2014).

7 Breniquet/Michel 2014; Nosch 2015; Sabatini 2018.

8 The wool chaîne opératoire includes sheep herding and husbandry practices, wool plucking, sorting, and cleaning, spinning, weaving, post-weaving treatments, and finally tailoring if clothing is to be pro- profitable - also attention to consumption patterns and involvement in trade, thus to be part of an overall political economic design. Raw wool itself, during the Bronze Age, appears to have been a precious and difficult raw material to obtain in large quantities, not to mention qualities ${ }^{9}$. Thanks to ancient written sources, we have rather precise indications as to quantity and quality of the wool obtainable from Bronze Age sheep in the eastern Mediterranean and Mesopotamia. Archive documents from the Aegean show for instance that the standard weight of a sheep fleece was 700-750 g, and mixed herds of ewes and lambs were expected to produce c. $300 \mathrm{~g}$ wool per animal ${ }^{10}$. The expected wool yield from ewes only would have been around $600 \mathrm{~g}^{11}$. Woollier sheep able to provide a yearly wool yield between 0.7 and $1.12 \mathrm{~kg}$ apparently existed in Mesopotamia, suggesting that at some locations, breeding practices improved specific productive traits ${ }^{12}$. Finally, Eastern Mediterranean wool economies had access to international wool trade and/or managed large numbers of sheep, which necessarily demanded well-organised herding strategies ${ }^{13}$.

Analyses of textile fragments from Bronze Age Europe hint at sheep fleeces resembling today's so-called primitive races such as Soay sheep ${ }^{14}$, which provide an annual wool yield similar to that documented in Aegean archives. As in the Aegean, a profitable continental wool production intended for export would have required access to large numbers of sheep. The possibility to generate intense sheep farming must have, therefore, played a key role for the emergence of continental wool economies. A wealth of evidence from the Terramare settlement of Montale (Modena province, northern Italy), suggests that the site was in the likely control of a large, and environmentally rich territory, in which sizeable herds could be favourably grazing, producing wool beyond subsistence necessities.

duced (cf. Andersson Strand 2014; Andersson Strand/Nosch, 2019; Barber 1991; Bender Jørgensen 2018, 68; Costin 2013; Gleba 2008; Sofaer et al. 2013, 477-482).

9 E. g. Andersson Strand 2014; Andersson Strand/Nosch 2019; Barber 1991, 20-30; Gleba 2008, 72-75.

10 Nosch 2014, 192; Del Freo et al. 2010, 341.

11 Rougemont 2014, 349-50.

12 Andersson Strand 2014, 44. Cf. also Ryder 1983, 28-29; Sabatini et al. 2019.

13 Arbuckle/Hammer 2018; Biga 2014, 141; Firth 2014; Foster 2014, 117; Matoïan/Vita 2014; McCorriston 1997, 523-524; Rougemont 2014, 241-45; Wisti Lassen 2010.

14 E. g. Rast-Eicher 2003; see also Gleba 2012. 


\section{The Terramare settlement at Montale}

Montale was one of the many fortified Terramare settlements on the Po plain. It was c. 1 ha in size, and it was surrounded by a ditch c. $40 \mathrm{~m}$ wide and $3 \mathrm{~m}$ deep, which was filled with water from a nearby river likely to serve several functions including defence ${ }^{15}$. Terramare populations inhabited the central Po plain from the beginning of the Italian Middle Bronze Age until the end of the local Recent Bronze Age (c. 1700/1650-1200/1150 BC). By the end of the Middle Bronze Age, a site hierarchy emerged with several settlements that reach up to $10-20$ ha in exten$\operatorname{sion}^{16}$. At the end of the Recent Bronze Age, this apparently prosperous system collapses for reasons that are widely debated ${ }^{17}$. Differently from other prominent sites on the plain, Montale does not change its original size and is probably abandoned before the end of the Recent Bronze Age ${ }^{18}$. The remains of the Bronze Age village were partly investigated during the nineteenth century providing information in particular about the still preserved parts of the embankment once separating the village from the water-filled ditch ${ }^{19}$. Thanks to recent stratigraphic excavations (carried out between 1996 and 2001) of a c. $45 \mathrm{~m}^{2}$ portion of the settlement spared during the manurequarry works in the nineteenth century ${ }^{20}$, a glimpse of the internal organization at the site and an eleven-phase internal chronology (see Tab. 1) was determined.

What makes Montale exceptional among Terramare settlements, and so far among European Bronze Age settlements in general ${ }^{21}$, is its extraordinarily high concentration of textile tools, particularly spindle whorls. Nearly 4500 spindle whorls are known from the site suggesting yarn production close to industrial scale ${ }^{22}$. The prevalence of sheep/goats among the faunal remains from the site has

15 Cardarelli/Labate 2009a, 28-30.

16 Cardarelli 2009b; 2015; Pacciarelli 2016.

17 Bernabò Brea et al. 1997b; Cardarelli 2009b; Cremaschi et al. 2006. 18 Cardarelli/Labate 2009b

19 Boni 1882; 1884; Cardarelli/Labate 2009a.

20 During the nineteenth century, numerous manure quarries were opened in the central Po plain. As it became rapidly evident, those quarries of fertile soil were no more than the remains of Bronze Age settlements (e. g. Bernabò Brea/Mutti 1994; Cardarelli 2009a, 16-18; Saltini 1997).

21 In the rest of Europe, other centres of wool production, such as for instance Százhalombatta-Földvár, in the Hungarian plain (Bergerbrant 2018; Vretemark 2010), certainly existed (see also Belanová Štolcova/Grömer 2010; Kneisel/Schaefer 2019); however more focused research is needed to document them.

22 Sabatini et al. 2018a.
Tab. 1: Montale's archaeological phases and contemporary Italian Middle and Recent Bronze Age chronology

\begin{tabular}{ll}
\hline Montale & Italy \\
\hline & Middle Bronze Age 1 \\
& $1700-1550$ BC \\
\hline Phase I & Middle Bronze Age 2A \\
& $1550-1500$ BC \\
\hline Phase II & Middle Bronze Age 2B \\
& $1500-1450$ BC \\
\hline Phases III-VI & Middle Bronze Age 3A \\
& $1450-1400$ BC \\
\hline Phases VII-VIII & Middle Bronze Age 3B \\
& $1400-1325 / 1300$ BC \\
\hline Phases IX-XI & Recent Bronze Age 1 \\
& $1325 / 1300-1225 / 1200$ BC \\
\hline & Recent Bronze Age 2 \\
& $1225 / 1200-1150$ BC \\
\hline
\end{tabular}

been used to support the hypothesis that wool was the main fibre manufactured there ${ }^{23}$; however, so far issues of pastoral economy at the site have not been investigated in depth.

\section{The Archaeozoology of wool}

Like most organic material, wool does not normally preserve in the archaeological record. With the exception of a single textile fragment from Castione dei Marchesi (Parma province), likely dating to the Middle Bronze $\mathrm{Age}^{24}$, no other remains of textiles are known from Terramare settlements. Studies on the local wool economy must, therefore, rely on the archaeozoological evidence for wool-producing animals, and the archaeological evidence for wool technology.

Studies of prehistoric sheep/goats demonstrated that a significant variety existed in animal size and morphological traits across prehistoric Europe ${ }^{25}$. Although archaeozoology cannot offer information as to the woolliness of their fleeces, it can help understand prehistoric herds' management. The slaughtering age of the animals suggests their primary use ${ }^{26}$. Adult sheep in general, and wethers

23 De Grossi Mazzorin/Ruggini 2009; Sabatini et al. 2018a.

24 Bazzanella 2012, 209.

25 e. g. Benecke 1994; Bökönyi 1974; Grömer/Saliari 2018, 135-136; Pipes et al. 2014; Ryder 1983; Schmölke et al. 2018.

26 Payne 1973; Greenfield 2014. 
in particular, produce the largest amount of wool ${ }^{27}$; high numbers of such individuals in a flock becomes, therefore, solid evidence of wool production. A high number of slaughtered new-born animals would instead suggest attention to milk products, while a primary interest in meat consumption would give herds with kill-off patterns clustering between approximately $6 / 9$ months and 2/3 years depending on access to winter fodder ${ }^{28}$.

Ancient written texts, in particular from Bronze Age Crete $^{29}$, show that local managements were well-aware of the amount of wool obtainable from different categories of sheep. Specialized herds also existed, but it seems that even in the case of distinct Bronze Age wool productions such as those carefully recorded in Aegean archive tablets, a mixed economy strategy, exploiting various products beside wool, was preferred ${ }^{30}$. When written documents are missing, some critical research questions concerning reliability of inferences from zoo-archaeological evidence must be considered as to the relations between estimated culling patterns, husbandry practices and wool production:

1) To what extent do percentages of different taxa among animal remains in a given place mirror the ancient local domestic fauna?

2) In which ways can finding circumstances bias our understanding of the ancient animal population?

The representativeness of the archaeozoological remains has been discussed in a number of forums ${ }^{31}$. As to the study of Bronze Age wool economy, two specific aspects appear particularly relevant; the numerical dimension of the ancient faunal population and the relation between sheep and goats.

The first problem regards the possibility to estimate the ancient animal population from excavated faunal assemblages. Archaeozoological evidence may be biased by various factors and so not provide a full picture of the relative proportions of ancient domesticated species $^{32}$. Two major issues shall be addressed in the case of Montale. First, the available faunal remains, although abundant (c. 9000 determined remains) ${ }^{33}$, and well documented, coming from modern stratigraphic excavations ${ }^{34}$, docu-

27 Barber 1991, 26-27.

28 Payne 1973, 282.

29 E. g. Del Freo et al. 2010; Killen 1964.

30 E. g. Halstead 1998; Payne 1973, 282.

31 E. g. Albarella 2017; Bartosiewicz et al. 2013; Peres 2010

32 E. g. Barber 1991, 27-28; Grömer/Saliari 2018, 128-129; Peres 2010.

33 De Grossi Mazzorin 2013.

34 Cardarelli 2009a. ment behaviour from only a small sample of the ancient Bronze Age village's living area. They may, therefore, be the results of depositional events that cannot be straightforwardly representative for the whole site. Secondly, social, cultural, religious, and practical rules or taboos might have biased the consumption patterns revealed by excavated remains.

To assess the first problem, one should consider that the archaeological evidence from the Terramare area broadly show regular settlement configurations with tightly organized living quarters of similar dimensions, repeatedly rebuilt throughout site sequences ${ }^{35}$. Montale does not seem to be an exception ${ }^{36}$; therefore, it is likely that the data acquired for the excavated portion would recur in other parts of the site. On the other hand, animal bones from the settlement ought to be predominantly the remains of meat consumption. Our current understanding of the Terramare societies does not allow to determine whether social, cultural or religious constrains may have influenced eating practices, and the assemblage composition.

Aware of limitations intrinsic to size and circumstances of the available sample, the reconstruction of the ancient pastoral economy at Montale shall be attempted by combining the evidence from archaeological studies with archaeozoological and archaeobotanical investigations, Thiessen polygon models, and strontium isotope tracing analyses. Finally, an attempt to quantify wool production and animal demography is provided. It is proposed that the approach developed by this research has the potential to construct a model useful to investigate other areas and periods as well.

\section{Montale's ancient animal population}

Animal remains from the modern excavations at Montale have been preliminarily published ${ }^{37}$. They suggest that the ancient animal population was largely domestic and that sheep/goats likely prevailed throughout the site sequence. Cattle represented a stable c. $10 \%$ of the bone assemblages and was typically kept until old age, thus likely used in agricultural work. Pigs' bone remains, which can be interpreted as a sign of mixed economy (pigs can be associated to the consumption of leftovers from agricultural produc-

35 See Bernabò Brea et al. 1997a; Bernabò Brea et al. 2007; Ferrari et al. 2018.

36 Cardarelli/Labate 2009b.

37 De Grossi Mazzorin/Ruggini 2009. 
tions) ${ }^{38}$, decreased considerably through time (Tab. 2), possibly in connection to sheep farming and secondary products acquiring a greater economic role ${ }^{39}$.

The available data about sheep/goat bone from Montale hint at a considerable animal population. Throughout the sequence, their remains dominate the bone assemblages (see Tab. 2). Additionally, their presence seems to increase from approximately $47 \%$ of the local faunal remains during the Middle Bronze Age 2 to c. $62 \%$ of the total during the Recent Bronze Age 1. The sample is not exclusively sheep ${ }^{40}$; on the exclusive base of traditional archaeozoological methods, it has been estimated that goats represent c. $8 \%$ of the domestic caprine population during most of the sequence (phases I-X, see Tab. 1), while during the last phase (XI) of the Recent Bronze Age 1, the percentage of goats doubles ${ }^{41}$. A similar pattern has also been observed in other Terramara sites where it has been interpreted as a sign of worsened environmental conditions ${ }^{42}$, since goats seem to have better chances than sheep to cope with adverse, drier circumstances. Across Eurasia since prehistory, sheep and goats have been kept together, although in varying proportions ${ }^{43}$. The reasons behind such pastoral strategies might be various ${ }^{44}$.

In order to propose a convincing picture of Montale's wool economy, only the estimated sheep population will be considered ${ }^{45}$, because the presence of goats might

38 cf. De Grossi Mazzorin 2013, 258.

39 De Grossi Mazzorin/Ruggini 2009.

40 Sheep and goats are close, but not equivalent species. Thanks to archaeozoology, and today to zooarchaeology by mass-spectrometry (ZooMS), and ancient DNA (aDNA) studies, it is possible to distinguish between their remains (e. g. Buckley et al. 2009; 2010; Campana et al. 2013; Sinding et al. 2015). While the ZooMS and the aDNA analyses tend to provide definitive results, archaeozoological analyses are limited in their scope by the fact that just a few bones can be used to distinguish between the two taxa (e.g. Salvagno/Albarella 2017; Halstead et al. 2002; Gillis et al. 2011).

41 De Grossi Mazzorin/Ruggini 2009.

42 Farello 2011.

43 E. g. Becker et al. 2016, Fig. 10; De Grossi Mazzorin 2013; Green 1980; Greenfield 2005, 22.

44 Both the primary and the secondary products that can be obtained from them have different nutritional values and different harvesting patterns when eatable (like milk and meat) or different characteristics when the main interest is in their skin/fleeces (see Greenfield 2017). Both species can be used to produce wool (e. g. Barber 1991, 20-30; Del Freo et al. 2010, 340; Green 1980, 14), although goat hair has not yet been detected in Bronze Age textiles from continental Europe. Evidence from the Aegean and the Near East (Bender Jørgensen/ Rast-Eicher 2018, 34; Frangipane et al. 2009, 19-20; Michél 2012, 237) suggest that they were in use in neighbouring areas.

45 According to the available data from De Grossi Mazzorin/Ruggini 2009.
Tab. 2: Approximate percentages of the domestic taxa recovered at Montale during the stratigraphic excavations 1996-2001.

\begin{tabular}{lcclll}
\hline & Sheep & Goats & $\begin{array}{l}\text { Total sheep/ } \\
\text { goats }\end{array}$ & Pigs & Cattle \\
\hline $\begin{array}{l}\text { Middle } \\
\text { Bronze Age 2 }\end{array}$ & $40 \%$ & $7,2 \%$ & $47,2 \%$ & $41,4 \%$ & $11,4 \%$ \\
\hline $\begin{array}{l}\text { Middle } \\
\text { Bronze Age 3 }\end{array}$ & $40 \%$ & $8 \%$ & $49,8 \%$ & $37,7 \%$ & $12,5 \%$ \\
\hline $\begin{array}{l}\text { Recent } \\
\text { Bronze Age 1 }\end{array}$ & $48 \%$ & $13,6 \%$ & $61,6 \%$ & $28,1 \%$ & $10,3 \%$ \\
\hline
\end{tabular}

imply that a percentage of the domestic caprines was not kept for wool.

\section{Thiessen polygons and archaeo- botanical records from Montale's territory}

A Thiessen polygon model associates settlements with their surrounding territories, and can be applied to the Modena province during the Bronze Age to associate settlements with resource areas. Despite its relatively small size (1 ha), Montale appear to have dominated, during its initial phases I-II (Middle Bronze Age 2), an unusually large territory of c. $2200 \mathrm{ha}^{46}$. According to the Thiessen polygons' model, the average size of the territories associated with the other Terramare sites of Modena's alta pianura (= part of the Po plain south of Modena, cf. Fig. 1) is a much more modest 260 to 890 ha. Of course, Thiessen polygons represent an abstract model, and other factors invisible to the archaeological record might affect regional landscaped management ${ }^{47}$; nonetheless, access to an extensive surrounding landscape would doubtlessly represent a crucial factor to the development of intense sheepherding targeted at wool production. Political control over a relatively wide territory would allow the Bronze Age Montale's community to carry out at the same time large-scale animal husbandry integrated with prosperous agriculture.

A substantial confirmation for the interconnected prosperity of Montale seems to come from the pollen diagrams. Pollen analyses from the Terramare area have shown that emphasis on pastoral economy is differen-

46 Cardarelli 2009c, 43-48.

47 Ibid. 


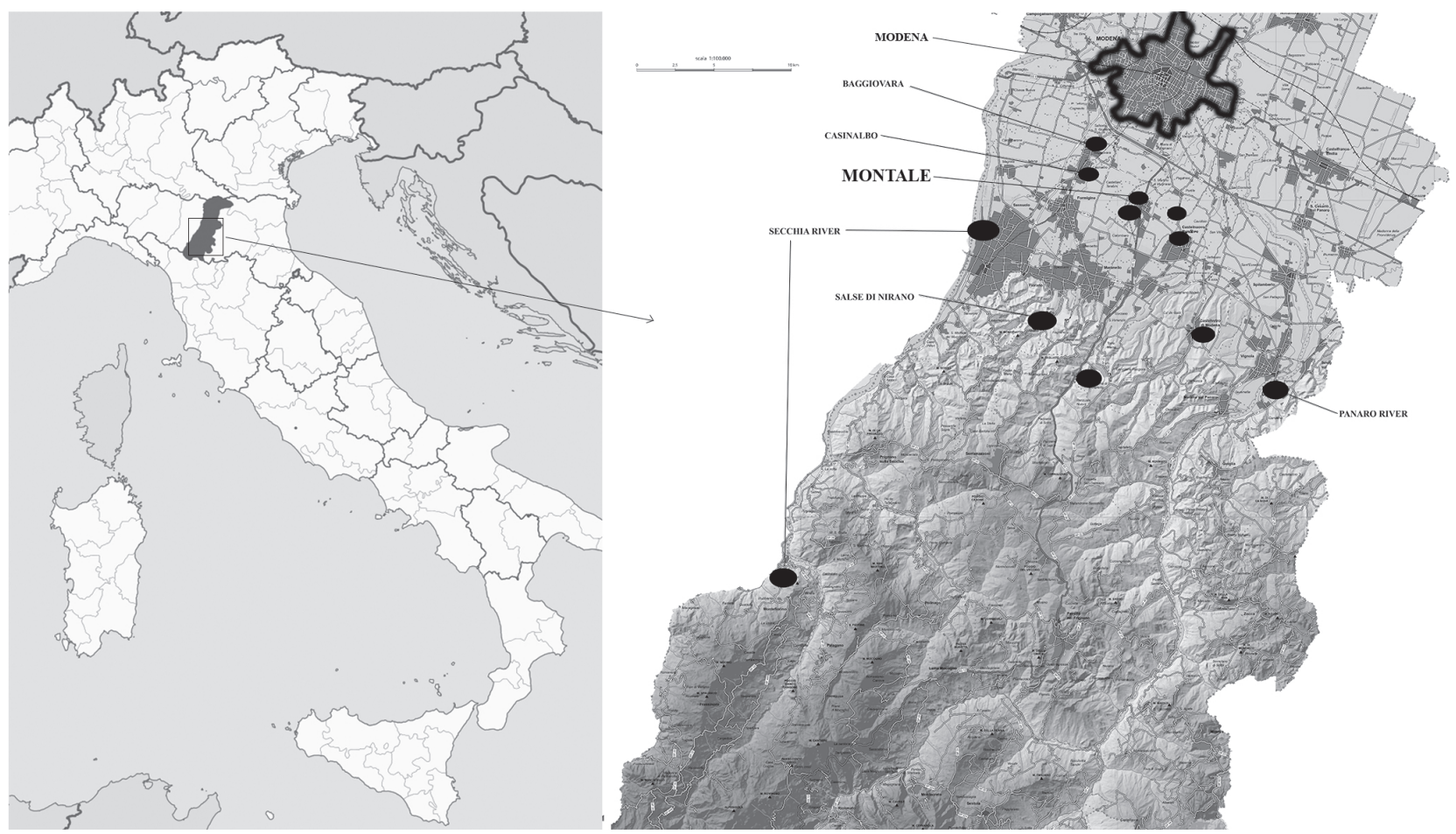

Fig. 1: Map of Italy indicating the Modena province and close up of Modena's alta pianura and neighbouring Appenine foothills with names of the sites mentioned in the text. The black ovals marks locations where samples for strontium isotope baseline have been collected (Graphics: S. Sabatini)

tial on the plain, and that not all the sites would pursue the same economic strategies. An important indicator for pasture and grazing land has been identified by the presence of cichorieae (one of the six tribes of the sub-family Cichorioidea) in pollen diagrams ${ }^{48}$. Pollen studies from Montale, as from the neighbouring site of Baggiovara, show a significant presence of chicorieae ${ }^{49}$, strongly suggesting that they were surrounded by a landscape where animal grazing had a relevant role. Pollen diagrams from other Terramare villages, such as the well-studied site of Poviglio, provide a different picture revealing a surrounding territory, with a prevalent agriculture and just few limited zones probably devoted to pastoral activities ${ }^{50}$.

As mentioned earlier, Montale is situated in the alta pianura (the southern margins of the Po plain) near the potential summer pastures offered by the Appenine Mountains, which were exploited for sheep raising in Roman times $^{51}$. Earlier studies, based on the archaeological evidence, have suggested interaction between the plain and those mountainous areas throughout the Middle and

48 Florenzano et al. 2015.

49 Accorsi et al. 2009; Mercuri et al. 2006, 55.

50 Cremaschi et al. 2016, 168.

51 Corti 2012.
Recent Bronze Age ${ }^{52}$. Although they did not provide conclusive evidence as to Bronze Age sheepherding, Montale's herds could potentially have had access to these mountainous pastures (or perhaps to forage harvested there). Although not proved, the possibility that Montale's community could exploit the mountainous pastures offered by nearby Appenine uplands is not contradicted by the geochemical analyses carried out at the site ${ }^{53}$.

\section{Strontium isotopes and Bronze Age husbandry practices at Montale}

Strontium isotopes have proven to be an interesting means to measure relationships between people, animals and organic material from the past and the landscape in which they were found ${ }^{54}$. Within the THESP project supporting the present work $^{55}$, a twofold series of strontium isotope

52 Cardarelli 2006; Cavazzuti/Putzuolo 2015.

53 Sabatini et al. forthcoming.

54 E. g. Frei et al. 2015, 2017.

55 See: https://historiskastudier.gu.se/english/research/bronzeage-wool-economy 
analyses was carried out to explore the characteristics of the pastoral economy at Montale, and in particular, to understand whether animal seasonal mobility was used to optimise landscape management. A primary goal of the sampling strategy has been to map the biologically available regional strontium baselines around Montale, including both the plain surrounding the site, and the neighbouring northernmost slopes of the Appennine Mountains ${ }^{56}$. The two largest rivers of the area, with a relatively consistent water flow all year around (Secchia to the west, and Panaro, to the east of Montale) were chosen as eastern and western borders of the studied area. They likely represented considerable landmarks ${ }^{57}$. The local baseline values have been measured in water and vegetal samples and in soil from different excavation layers at both the site of Montale and at the neighbouring and roughly contemporary necropolis of Casinalbo ${ }^{58}$.

The second aim of the sampling strategy was to collect sheep teeth from the stratigraphic excavations at Montale to provide evidence to test pastoral mobility. Thirty-five teeth (between two and five per each 11 archaeological phases investigated at the site, Tab, 1) have been sampled for strontium isotope analyses ${ }^{59}$. Most teeth have been subjected to multiple sampling to investigate mobility through time in the same animal individuals ${ }^{60}$. The results of the analyses are in course of publication and cannot therefore be provided here. For the scope of this paper, one can say that they are not in contradiction with the hypothesis put forward in this paper that domestic caprines primarily grazed in the territory around Montale, and possibly, if convenient, used Appennine mountain pastures ${ }^{61}$.

56 Sabatini et al. 2018b, Fig. 1.

57 An indirect confirmation of their geographical role might be considered the somewhat different development of the area at the end of the Middle Bronze Age. In the whole Terramare area by the end of the Middle Bronze Age 3 and more clearly during the Recent Bronze Age, site hierarchy emerges with large sites dominating vast portions of the landscape. In the alta pianura between Secchia and Panaro, the earlier Middle Bronze Age political situation would seem to remain rather unchanged.

58 Sabatini et al. forthcoming. About the necropolis of Casinalbo see Cardarelli 2014.

59 Sabatini et al. 2018b.

60 Cf. Sabatini et al. forthcoming.

61 Sabatini et al. forthcoming

\section{Animal demography and wool economy: attempting quantification}

\section{Sheep grazing and stocking rates}

In terms of pastoral economies, various attempts have been done to calculate the amount of land necessary for successful prehistoric sheepherding ${ }^{62}$. The extent of grazing land varies greatly depending on climate, environmental factors (i.e. characteristics of the vegetation, access to fresh water, weight and size of the grazing animals) and the degree of human intervention and regulation ${ }^{63}$. Desert pastures similar to those available for southern Mesopotamian Bronze Age wool economies would need between 6-8 ha to support one sheep in a year, while in the steppe environment of northern Mesopotamia this figure would decrease to 4.5 ha. Probably, about 24.5 ha would be necessary to produce around $3 \mathrm{~kg}$ of raw wool in a year or $2 \mathrm{~kg}$ of clean/ready to use wool in the south, and 15.75 ha, in the north of Mesopotamia ${ }^{64}$. On the northern edge of western Eurasia, 1 ha of actively managed heathland could sustain one adult double-coated old Norse sheep, producing $1-2 \mathrm{~kg}$ of raw wool per year ${ }^{65}$. Long-term investigations on the feral Soay population living in the Village Bay sector (c. 175 ha) of the Hirta Island, Scotland, UK, have shown that even when the human intervention is practically non-existent, a harsh environment could sustain between 313 and 423 sheep between 1961 and 1967 and from 211 to 513 animals during the period 1985-1990; thus, between 1.2 and 2.9 animals per hectare ${ }^{66}$.

Controlled grazing may increase the number of animals in a given landscape and guarantee - i.e. by storing surplus vegetation from the spring/summer seasons - adequate food intake during the winter months ${ }^{67}$. Controlled grazing and rotational practices, including multispecies grazing, seem to provide ecological and economic advantages and to a certain extent higher resistance to parasites, toxic plants, and predators ${ }^{68}$. Ethnographical studies show that traditional pastoral societies actively practice forms of rotation and controlled grazing ${ }^{69}$. Archaeobotan-

62 E. g. Becker et al. 2016, 109-112; Bendrey 2011; Gregg 1988, 111-118; Hadjigeorgiou et al. 2005; Randall 2010, 29-82.

63 E. g. Avondo et al. 2013; Grace et al. 2018; Milligan et al. 2016; Molle et al. 2001; 2004.

64 McCorriston 1997, 524.

65 Bender Jørgensen 2012, 179.

66 Clutton Bruck et al. 1991.

67 E. g. Molle et al. 2004, 197.

68 E. g. Esmail 1991; Randall 2010, 43-50; Walker 1994.

69 Elliott et al. 2014; Randall 2010, 40; Sieff 1997, 526-531. 
ical studies from Montale seem to confirm that the immediate benefits of such practices were exploited by local community (Mercuri et al. 2006).

A study from Virginia, USA, shows that a modern supposedly 'safe' rate of 2.5 sheep/acre (c. 5 animals per ha) in favourable environmental conditions can be doubled with controlled grazing ${ }^{70}$. A survey of modern controlled farming from New Zealand for the period 1987-1990 reports an average eight stock units (each unit consisting of one ewe and one lamb) for summer dry properties and 10.8 stock units for summer moist pastures ${ }^{71}$. Similar rates are obtained in Sardinia, where irrigated lowlands can apparently be grazed by $10-20$ ewe/ha, while the dry hills by 1-3 animal $/ \mathrm{ha}^{72}$. Studies on the Appennine mountains of the Parma province, in northern Italy, show a subsistence capacity similar to that estimated for the Sardinian hills, with rates between 0.97 and 3.93 sheep $/ \mathrm{ha}^{73}$. As to the scope of this work, one should consider that Modena province's alta pianura during the Bronze Age probably offered relatively good quality pastures all year around, thus high stocking rates (or numbers of animal per units of land). Today, local farmers report that seven to nine sheep per hectare is a convenient stocking rate ${ }^{74}$. In Roman times, a few kilometres north-east of Montale at the site of Baggiovara, 2 sheep/ha was average for small-scale, single-family farms following a mixed subsistence economic model ${ }^{75}$. Modern organic farming standards recommend for average quality pastures a sustainable stocking rate at 1.2 livestock units (1 livestock unit $=5$ domestic caprines) per ha ${ }^{76}$. In Italy, current standards for organic farms have set a maximum number of sheep per hectare at 13.3 animals $^{77}$. According to a study of grazing methods in modern semi-arid Mediterranean conditions, natural pastures appear suitable for a low-medium rate of 1-5 heads/ha; forage crops of grass and legumes can sustain medium-high rates of 5-10 heads/ha, while high-quality forage crops and legumes support generally high rates of $10-15$ heads $/ \mathrm{ha}^{78}$.

To calculate carrying-capacity rates for the territory of Montale, one should consider that modern rates target bigger and heavier sheep (with adults ewes from 60 up to $130 \mathrm{~kg}$ as in the case for instance of the Suffolk breed)

70 Kintzel 2010; Umberger 2009.

71 Cacho et al. 1995, 44.

72 Hadjigeorgiou et al. 2005, 53.

73 Superchi et al. 2007

74 Andrea Cardarelli, University of Rome La Sapienza, personal communication.

75 Labate 2011, 31.

76 Randall 2010, 42.

77 Vizioli 2015.

78 Molle et al. 2004, 197. than more 'primitive' sheep such as the Soays (adult ewes generally between $25-30 \mathrm{~kg}$ ). The latter are, as mentioned above, able to survive at low-medium stocking rates even in the unmanaged harsh north-Atlantic landscape of Hirta Island, Scotland. Thus, Bronze Age sheep farming could likely use a more convenient coefficient of animal/ha than those applied for modern herding. Additionally, light primitive sheep cause a generally limited degree of damage when it comes to trampling of the grazed land - supposedly effecting a faster recovery of the vegetation throughout the year ${ }^{79}$. A confirmation that Bronze Age sheep from the Po valley would resemble Soay sheep in size comes from archaeozoological studies revealing that the average withers' height is c. $60 \mathrm{~cm}$ or below ${ }^{80}$. Soay sheep's wither height is around $52 \mathrm{~cm}$ for ewes and $56 \mathrm{~cm}$ for rams ${ }^{81}$.

The information just summarized show that it is possible, although hypothetical, to attempt to reconstruct stocking rates for the sheep population in given landscapes. In the case of Montale, considering: 1) its vicinity to potential mountainous pastures on the neighbouring Appenine, 2) the small size of the Bronze Age sheep, 3) the likely good quality of the pastures, and 4) the abundance of water, the local territory was probably able to support significant stock rates, between at least 5 to 10 domestic caprines per hectare.

\section{Sheep stocking rates and other domestic fauna}

To calculate the stocking rates proposed in the following models (Tab. 3-5), it has been considered that other domestic fauna were also present in the area.

Around $10 \%$ of the local animal remains throughout the site sequence (Tab. 2) belong to cattle, this number paired with the advanced age of the analysed animals suggest that cattle were used primarily as aid in the agricultural work ${ }^{82}$. The absolute number of cattle at the site was probably limited to a few per household and thus likely well below a stocking rate of one animal/ha. Multispecies grazing experience suggests that one cattle per more than one hectare otherwise used for sheep should not alter the food intake of the prevailing species since they eat different forage. Additionally, the Bronze Age cattle from the plain appear to have been relatively small

79 E. g. Blakesley/Buckley 2016, 73-74.

80 De Grossi Mazzorin 2013, 258; see also Riedel 1996, 53-54.

81 Alderson 2016, 915.

82 De Grossi Mazzorin/Ruggini 2009. 
in size with a withers' height around $110 \mathrm{~cm}^{83}$, thus probably needed a lower food intake than modern cattle.

Pigs represent the second most common domestic taxa at Montale (Tab. 2); their diet is often thought to have been largely human leftovers and temporary browsing in forested $\operatorname{areas}^{84}$, which would be quite consistent (660$436 \mathrm{ha}$ ) in the hypothetically calculated Montale's territory. Hence, they too would hardly affect sheep's grazing.

Goats have the same stocking rates as sheep ${ }^{85}$, and are obviously present in a relatively rather stable 4:1 ratio throughout all phases (I-X), but one (phase XI) when the ratio raise to almost 4:2. All the same, goats normally target different plants than sheep, and in the ratios evident at Montale, they could profitably graze on the same landscape without interfering with each other as to food intake ${ }^{86}$.

The figures proposed, that feature 2-5 sheep/ha or modern low-medium stocking rates ${ }^{87}$, are probably modest; however, they should allow excluding the other domestic taxa (cattle, goat and pigs) from the modelling without affecting the potential significance of projected results.

\section{Sheep and wool economy at Montale}

About 1 hectare of land per person would secure agricultural subsistence ${ }^{88}$ and with an estimated population of between 120-130 individuals at Montale, perhaps 130 hectares of land immediately around the settlement should have been dedicated to agricultural production. It has been assessed that the landscape around Terramare settlements was generally managed as following: c. $20 \%$ of the available land was devoted to agriculture, between $20 \%$ and $40 \%$ was covered by forest, while the remaining $40 \%$ to $60 \%$ of the land was used for pasture ${ }^{89}$. Pollen diagrams from Montale suggests that c. $30 \%$ of the territory surrounding the site was forested ${ }^{90}$, thus the remaining $50 \%$ could have been grazing land.

The Thiessen polygon model suggests that, during the Middle Bronze Age 2, Montale could have controlled a ter-

83 De Grossi Mazzorin 2013, 261; Riedel 1996, 54.

84 De Grossi Mazzorin 2013, 258; Gregg 1988, 118-123; Randall 2010, 49.

85 Cf. Eurostat LSU.

86 Cf. Elias/Tischew 2016.

87 Molle et al. 2004, 197.

88 Cardarelli 2009b, 461; 2009c, 44.

89 Cardarelli 2009b, 461.

90 Cremaschi et al. 2016, 168; Mercuri et al. 2006, 263. ritory of $2200 \mathrm{ha}^{91}, 20 \%$ of which is 440 ha or well beyond that required to support the settlement's small population. Results open up for at least two possibilities; in the first case (scenario A), Montale's inhabitants could have been practising agriculture that produced surplus for export. In the second case (scenario B), a considerably lower percentage (around $6 \%$ ) of the territory around the site could have been used for subsistence. Maintaining that $30 \%$ (or $660 \mathrm{ha}$ ) was forested and generally used for other purposes than sheep farming, the remaining $50-64 \%$ of the land (c. 1100-1400 ha) could have been devoted to grazing of the local domestic caprines. Quantifications are therefore proposed in two different scenarios (Tab. 3-5):

A) Intense agriculture (both agriculture and sheep-farming are export-oriented)

B) Subsistence agriculture (only sheep-farming is export-oriented)

\section{Middle Bronze Age 2}

The proposed model (Tab. 3) largely confirms the hypothesis that Montale was an early centre of wool production and export ${ }^{92}$. Despite using a combination of low coefficients (a modest low-medium stocking rate of 2-5 sheep/ ha, and an annual wool yield of c. $300 \mathrm{~g}$ of wool per animal $)^{93}$, modelling show that the hypothetical territory of Montale could support an animal population between 2640 (at 2 heads/ha) and 6600 animals (at 5 heads/ha). Using as a frame of reference production figures proposed by Eva Andersson Strand and Marie-Louise Nosch ${ }^{94}$ and considering that a third of the raw wool would have been discarded during cleaning, Montale's territory could easily deliver slightly over 1.3 ton of clean ready to use wool per year.

Since the archaeological evidence suggest yarn production at Montale close to an industrial scale ${ }^{95}$, it is likely that locally produced wool was cleaned and spun at the site for export. At an average speed of $40 \mathrm{~m}$ per hour to obtain a middle range thread ${ }^{96}$, we get a workload for the hypothetical maximum amount of wool per year (Tab. 3 scenario B), of about 380.000 hours. The latter would

91 Cardarelli 2009b, 462.

92 Sabatini 2018; Sabatini et al. 2018a.

93 According to Bronze Age Aegean archive $300 \mathrm{~g}$ of wool per animal is the expected yield of a mixed flock with only ewes and lambs (e.g. Del Freo et al. 2010; Nosch 2014).

94 Andersson Strand/Nosch 2019, 22-24

95 Sabatini et al. 2018a.

96 Andersson Strand/Nosch 2019, Tab. 2,1. 
Tab. 3: Hypothetical quantification of average wool production at Montale during the Middle Bronze Age 2 (calculations about time, fibre and labour consumption are based on Andersson Strand/Nosch 2019, Tab. 2,1)

\begin{tabular}{|c|c|c|c|c|c|c|c|}
\hline $\begin{array}{l}\text { Farming land } \\
\text { at Montale } \\
\text { (BM2) }\end{array}$ & Scenarios & $\begin{array}{l}\text { Total available } \\
\text { pasture (ha) }\end{array}$ & $\begin{array}{l}\text { Number } \\
\text { of sheep } \\
\text { per ha }\end{array}$ & $\begin{array}{l}\text { Sheep } \\
\text { population } \\
\text { size }\end{array}$ & $\begin{array}{l}\text { Minimum } \\
\text { Wool yield per } \\
\text { year (c. } 300 \mathrm{~g} \\
\text { per animal) }\end{array}$ & $\begin{array}{l}\text { Spinning } 1 \mathrm{~kg} \mathrm{wool}= \\
10.310 \mathrm{~m}(40 \mathrm{~m} / \mathrm{h})\end{array}$ & $\begin{array}{l}\text { Approximate } \\
\text { number of } 1 \times \\
2.5 \mathrm{~m} \text { tabby } \\
\text { weave that could } \\
\text { be produced }\end{array}$ \\
\hline \multirow[t]{4}{*}{$\begin{array}{l}1540 \text { ha } \\
(=2200 \\
\text { ha }-660 \text { ha } \\
{[30 \%] \text { of }} \\
\text { forested area })\end{array}$} & \multirow[t]{2}{*}{$\begin{array}{l}\text { A) Intense } \\
\text { agriculture } \\
\text { (c. } 440 \text { ha) }\end{array}$} & \multirow[t]{2}{*}{$\begin{array}{l}1100+220 \\
\text { of 'resting' } \\
\text { agricultural } \\
\text { land }=1320 \text { ha }\end{array}$} & 2 & 2640 & $\begin{array}{l}792 \mathrm{~kg} \\
\text { (c. } 528 \mathrm{~kg} \text { of } \\
\text { clean wool) - }\end{array}$ & $\begin{array}{l}5443680 \mathrm{~m} \text { of yarn at } \\
136092 \text { hours (c. } 17011 \\
\text { working days at } 8 \mathrm{~h} / \text { day } \\
=46 \text { years/persons per } \\
\text { year) }\end{array}$ & 528 \\
\hline & & & 5 & 6600 & $\begin{array}{l}1980 \mathrm{~kg} \\
\text { (c. } 1320 \mathrm{~kg} \\
\text { clean wool) }\end{array}$ & $\begin{array}{l}13609200 \mathrm{~m} \text { of yarn at } \\
340230 \text { hours (c. } 42528 \\
\text { working days at } 8 \mathrm{~h} / \text { day } \\
=116 \text { years/persons per } \\
\text { year) }\end{array}$ & 1320 \\
\hline & \multirow[t]{2}{*}{$\begin{array}{l}\text { B) Sub- } \\
\text { sistence } \\
\text { agriculture } \\
\text { (c. } 130 \text { ha) }\end{array}$} & \multirow[t]{2}{*}{$\begin{array}{l}1410+65 \\
\text { of 'resting' } \\
\text { agricultural } \\
\text { land }=1475 \text { ha }\end{array}$} & 2 & 2950 & $\begin{array}{l}885 \mathrm{~kg} \\
\text { (c. } 590 \mathrm{~kg} \text { of } \\
\text { clean wool) - }\end{array}$ & $\begin{array}{l}6082900 \mathrm{~m} \text { of yarn at } \\
152072 \text { hours (c. } 19009 \\
\text { working days at } 8 \mathrm{~h} / \text { day } \\
=52 \text { years/persons per } \\
\text { year) }\end{array}$ & 590 \\
\hline & & & 5 & 7375 & $\begin{array}{l}2212.5 \mathrm{~kg} \\
\text { (c. } 1475 \mathrm{~kg} \text { of } \\
\text { clean wool) }\end{array}$ & $\begin{array}{l}15207250 \mathrm{~m} \text { of yarn and } \\
380181 \text { hours (c. } 47522 \\
\text { working days at } 8 \mathrm{~h} / \text { day } \\
=130 \text { years/persons per } \\
\text { year) }\end{array}$ & 1475 \\
\hline
\end{tabular}

make c. 47.000 working days (at 8 hours per day) ${ }^{97}$, which is a 130 years long occupation for one person or a yeararound labour for 130 craft-workers. 130 people would be the entire settlement population and thus entailing a critical workload for the community, which could be compensated for instance with the help of workers from outside the settlement, or with intense spinning carried out by the whole community during evening hours, or by trading part of the wool as a raw material.

In a fully developed economy such figures would entail producing the necessary yarn for weaving from approximately 528 (lowest figure in scenario A) to 1475 (highest figure in scenario B) balanced tabby weave of $1 \mathrm{~m}$ $\times 2.5 \mathrm{~m}$ (Tab. 3) $)^{98}$. Even in the unlikely case of c. 130 pieces of cloth distributed every year to each member of the local

97 We have no possibility to infer the average working hours of craft-worker during the European Bronze Age, however, recent experiments have shown that a skilled spinner today would produce an amount of yarn similar to those reported in Mesopotamian archives when working an average of 8 hours per day (Andersson Strand/Cybulska 2012).

98 Cf. Andersson Strand/Nosch 2019, Tab. 2,1. population, the figures clearly show the necessary hard work, but also the potential economic profits from the local wool economy.

\section{Middle Bronze Age 3}

During the Middle Bronze Age 3, the Thiessen polygon model suggests that the Montale's territory shrunk to around $1530 \mathrm{ha}^{99}$. The archaeological evidence from the stratigraphic excavations show a more limited number of textile tools during phases III-VIII than in the previous Middle Bronze Age 2 phases, however, the limited size of the excavated area might easily affect the reliability of such data ${ }^{100}$. The relative presence of sheep/goats among the archaeozoological material did not change. One could, therefore, imagine a slightly more intense, in

99 Cardarelli 2009c, Fig. 38.

100 It is relevant to consider that during phase $\mathrm{V}$ the excavated area features metallurgical activities and that during phase VII it hosts a granary (Cardarelli/Labate 2009b), thus no textile work could have been profitably going on there during at least these two phases. 
Tab. 4: Hypothetical quantification of average wool production at Montale during the Middle Bronze Age 3 (calculations about time, fibre and labour consumption are based on Andersson Strand/Nosch 2019, Tab. 2,1)

\begin{tabular}{|c|c|c|c|c|c|c|c|}
\hline $\begin{array}{l}\text { Farming land } \\
\text { at Montale } \\
\text { (BM3) }\end{array}$ & Scenarios & $\begin{array}{l}\text { Total available } \\
\text { pasture (ha) }\end{array}$ & $\begin{array}{l}\text { Number } \\
\text { of sheep } \\
\text { per ha }\end{array}$ & $\begin{array}{l}\text { Sheep } \\
\text { population } \\
\text { size }\end{array}$ & $\begin{array}{l}\text { Minimum } \\
\text { Wool yield per } \\
\text { year (c. } 300 \mathrm{~g} \\
\text { per animal) }\end{array}$ & $\begin{array}{l}\text { Spinning } 1 \mathrm{~kg} \text { wool = } \\
10.310 \mathrm{~m}(40 \mathrm{~m} / \mathrm{h})\end{array}$ & $\begin{array}{l}\text { Approximate } \\
\text { number of } 1 \times \\
2.5 \mathrm{~m} \text { tabby } \\
\text { weave that could } \\
\text { be produced }\end{array}$ \\
\hline \multirow[t]{6}{*}{$\begin{array}{l}1071 \text { ha } \\
(=1530 \\
\text { ha }-459 \text { ha } \\
\text { [30\%] of } \\
\text { forested area) }\end{array}$} & \multirow[t]{3}{*}{$\begin{array}{l}\text { A) Intense } \\
\text { agriculture } \\
\text { (c. } 214 \text { ha) }\end{array}$} & \multirow[t]{3}{*}{$\begin{array}{l}857+107 \\
\text { of 'resting' } \\
\text { agricultural } \\
\text { land }=964 \text { ha }\end{array}$} & 2 & 1928 & $\begin{array}{l}578.4 \mathrm{~kg} \\
\text { (c. } 385 \mathrm{~kg} \text { of } \\
\text { clean wool) - }\end{array}$ & $\begin{array}{l}3969350 \mathrm{~m} \text { of yarn at } \\
99234 \text { hours (c. } 12404 \\
\text { working days at } 8 \mathrm{~h} / \text { day = } \\
\text { c. } 35 \text { years/persons per } \\
\text { year) }\end{array}$ & 385 \\
\hline & & & 5 & 4820 & $\begin{array}{l}1446 \mathrm{~kg} \\
\text { (c. } 964 \mathrm{~kg} \\
\text { clean wool) }\end{array}$ & $\begin{array}{l}9938840 \mathrm{~m} \text { of yarn at } \\
248471 \text { hours (c. } 31059 \\
\text { working days at } 8 \mathrm{~h} / \text { day } \\
=84 \text { years/persons per } \\
\text { year) }\end{array}$ & 964 \\
\hline & & & 7 & 6748 & $\begin{array}{l}2024 \mathrm{~kg} \\
\text { (c. } 1350 \mathrm{~kg} \text { of } \\
\text { clean wool) }\end{array}$ & $\begin{array}{l}13918500 \mathrm{~m} \text { of yarn at } \\
347962.5 \text { hours (c. } 43 \\
495 \text { working days at } 8 \mathrm{~h} / \\
\text { day }=119 \text { years/persons } \\
\text { per year) }\end{array}$ & 1350 \\
\hline & \multirow[t]{3}{*}{$\begin{array}{l}\text { B) Sub- } \\
\text { sistence } \\
\text { agriculture } \\
\text { (c. } 130 \mathrm{ha} \text { ) }\end{array}$} & \multirow[t]{3}{*}{$\begin{array}{l}941+65 \\
\text { of 'resting' } \\
\text { agricultural } \\
\text { land }=1006 \text { ha }\end{array}$} & 2 & 2012 & $\begin{array}{l}603.6 \\
\text { (c. } 402 \mathrm{~kg} \text { of } \\
\text { clean wool) }\end{array}$ & $\begin{array}{l}4148744 \mathrm{~m} \text { of yarn at } \\
103719 \text { hours (c. } 12965 \\
\text { working days at } 8 \mathrm{~h} / \text { day } \\
=35 \text { years/persons per } \\
\text { year) }\end{array}$ & 402 \\
\hline & & & 5 & 5030 & $\begin{array}{l}\text { kg } 1509 \\
\text { (c. } 1006 \mathrm{~kg} \text { of } \\
\text { clean wool) }\end{array}$ & $\begin{array}{l}10371860 \mathrm{~m} \text { of yarn and } \\
259296 \text { hours (c. } 32412 \\
\text { working days at } 8 \mathrm{~h} / \text { day } \\
=88 \text { years/persons per } \\
\text { year) }\end{array}$ & 1006 \\
\hline & & & 7 & 7042 & $\begin{array}{l}2112.6 \text { (c. } \\
1408 \mathrm{~kg} \text { of } \\
\text { clean wool) }\end{array}$ & $\begin{array}{l}14516480 \mathrm{~m} \text { of yarn at } \\
362912 \text { hours (c. } 45364 \\
\text { working days at } 8 \mathrm{~h} / \text { day } \\
=124 \text { years/persons per } \\
\text { year) }\end{array}$ & 1408 \\
\hline
\end{tabular}

terms of stocking rates, sheep farming (Tab. 4). Indeed, a somewhat higher stocking rate of seven sheep per hectare (which was probably still an easily sustainable rate) would provide production figures similar to those from the earlier Middle Bronze Age 2 (Tab. 4).

\section{Recent Bronze Age 1}

During the Recent Bronze Age 1 (Montale's phases IX-XI), there is a marked decrease of textile tools in the archaeological record; however, archaeological preservation for the last phases (IX-XI) was poor. No structures could be identified, which strongly limits knowledge of that period $^{101}$. Interestingly, during this period a considerable increase of sheep/goat animal bones has been detected, while in the last phase (XI), the percentage of goats increase consistently suggesting additional economic transformations.

Terramare societies appear to have been oriented towards exploitation of their immediate territories with surplus productions to be used in exchange for non-local commodities ${ }^{102}$. Archaeobotanical samples from the modern excavations suggest several consistent transfor-

101 Cardarelli/Labate 2009b. 102 Sabatini et al. 2018a, 379. 
mations of the landscape around Montale during this period. In the first place, the forested area decreased from c. $30 \%$ to $20 \%$ of the total land surface ${ }^{103}$. Cereals also decrease in the pollen diagrams, data possibly confirmed by a contemporary sharp diminution of pigs that consumed agriculture leftovers (Tab. 2). On the other hand, already at the end of Phase VIII and more evidently in Phase IX, the cultivation of grape - previously non-existent in the local pollen diagrams - is introduced ${ }^{104}$. Perhaps grape and its by-products (i. e. wine), might have replaced other activities such as yarn and/or textile production to obtain exchangeable export products. Thanks to an increased diversification of productive activities, raw wool might for instance have become a more profitable export than yarn or clothing ${ }^{105}$.

According to the Thiessen polygons model Montale's landscape during this period would be of c. $2180 \mathrm{ha}^{106}$. Given the transformations in agricultural practices and land-management, it is difficult to estimate the area of pasturage; however, if one considers that the forested areas is now much smaller than during the Middle Bronze Age, an increased $10 \%$ of the available land could have been used for increased sheep and especially goat raising. Applying the same coefficients of 2-7 sheep/ha proposed for the Middle Bronze Age 3 (Tab. 4), Montale's territory could have produced an expanded annual wool yield (Tab. 5). The hypothetical labour required to clean and spin such amount of wool would - in particular in the case of seven sheep/ha - exceed the workload that the community could reasonably meet, thus theoretically supporting the idea of an economic transformation entailing production and trade in raw wool.

\section{Montale's pastoral economy: concluding remarks}

The archaeological evidence for textile tools combined with the archaeozoological indications of a significant sheep/goat population have led to the proposal that the Terramare site of Montale was an early centre of largescale wool production for export ${ }^{107}$.

Wool economy is a complex endeavour entailing a long chain of working processes and the interplay of

103 Accorsi et al. 2009; Mercuri et al. 2006.

104 Accorsi et al. 2009, 67; Cardarelli et al. forthcoming.

105 Sabatini et al. 2018a, 373.

106 Cardarelli 2009c, Fig. 41.

107 Sabatini et al. 2018a. several actors ${ }^{108}$. In the Aegean and the Near East, early wool economies seem to have been the outcome of precise choices managed, and strictly controlled by the central political authorities ${ }^{109}$. European Bronze Age communities, however, had fundamentally different social and political organizations than those of contemporary Mediterranean and Near Eastern societies ${ }^{110}$. The European societies were unlikely able to control at once large workforces, wide territories, and extensive trade routes. Therefore, engagement in a profitable surplus-oriented wool economy must have been possible only in the presence of favourable environmental, social, and/or economic preconditions. The small size of Bronze Age sheep and the limited amount of wool yield per head/year must have represented a major problem. Access to wide pastoral landscape and the possibility to organize intense sheepherding near a settlement would have created primary economic factors enabling what would have supported the rise of local wool economies. The aim of this paper has been to assess whether such a wool economy was possible at Montale, and at the same time, to provide a model for comparable studies in other settlement and/or environmental contexts.

Different data sets have been combined and discussed including archaeozoological and archaeobotanical studies, Thiessen polygon models, and to a minimum extent strontium isotope tracing analyses. The results show that Montale likely controlled an unusually extensive landscape, a considerable portion of which served for animal grazing. The site is also characterised by a strategic geographical position in close vicinity to possible summer pastures in the Appennine Mountain (cf. Fig. 1). Considering in particular, the economic value of their wool, herds likely grazed close to the settlement, but could potentially have used nearby mountain pastures. Considering the difficulties represented by the relatively homogenous bioavailable strontium isotope of the entire Emilia-Romagna region ${ }^{111}$, the strontium measured in local sheep teeth ${ }^{112}$, cannot probably confirm, but certainly makes a case for, the idea that what could be the local environmental comparative advantage was potentially fully exploited by Montale's community.

In order to provide a frame of reference to discuss the nature and size of the local wool economy, it has been

108 Andersson Strand 2014; Andersson Strand/Nosch 2019; Bender Jørgensen 2018; Costin 2013.

109 Breniquet/Michel 2014; Killen 1997; McCorriston 1997; Michel 2014; Michel/Nosch 2010; Nosch 2014, 2015.

110 Cf. Earle/Kristiansen 2010; Harding/Fokkens 2013.

111 Cavazzuti et al. 2019.

112 Sabatini et al. forthcoming. 
Tab. 5: Hypothetical quantification of average wool production at Montale during the Recent Bronze Age 1 (calculations about time, fibre and labour consumption are based on Andersson Strand/Nosch 2019, Tab. 2,1)

\begin{tabular}{|c|c|c|c|c|c|c|c|}
\hline $\begin{array}{l}\text { Farming land } \\
\text { at Montale } \\
\text { (RB1) }\end{array}$ & Scenarios & $\begin{array}{l}\text { Total available } \\
\text { pasture (ha) }\end{array}$ & $\begin{array}{l}\text { Number } \\
\text { of sheep } \\
\text { per ha }\end{array}$ & $\begin{array}{l}\text { Sheep } \\
\text { population } \\
\text { size }\end{array}$ & $\begin{array}{l}\text { Minimum } \\
\text { Wool yield } \\
\text { per year } \\
\text { (at c. } 300 \mathrm{~g} \\
\text { per animal) }\end{array}$ & $\begin{array}{l}\text { Spinning } \\
1 \mathrm{~kg} \text { wool }=10.310 \mathrm{~m} \text { (at } \\
40 \mathrm{~m} / \mathrm{h})\end{array}$ & $\begin{array}{l}\text { Approximate } \\
\text { number of } 1 \times \\
2.5 \mathrm{~m} \text { tabby } \\
\text { weave that could } \\
\text { be produced } \\
\end{array}$ \\
\hline \multirow[t]{6}{*}{$\begin{array}{l}1744 \text { ha } \\
(=2180 \\
\text { ha }-436 \text { ha } \\
{[20 \%] \text { of }} \\
\text { forested area })\end{array}$} & \multirow[t]{3}{*}{$\begin{array}{l}\text { A) Intense } \\
\text { agriculture } \\
\text { (c. } 348 \text { ha) }\end{array}$} & \multirow[t]{3}{*}{$\begin{array}{l}1396+174 \\
\text { of 'resting' } \\
\text { agricultural } \\
\text { land }=1570 \text { ha }\end{array}$} & 2 & 3140 & $\begin{array}{l}942 \mathrm{~kg} \\
\text { (c. } 628 \mathrm{~kg} \text { of } \\
\text { clean wool) }\end{array}$ & $\begin{array}{l}6474680 \mathrm{~m} \text { of yarn at } \\
161867 \text { hours (c. } 20233 \\
\text { working days at } 8 \mathrm{~h} / \text { day }= \\
\text { c. } 55 \text { years/persons per } \\
\text { year) }\end{array}$ & 628 \\
\hline & & & 5 & 7850 & $\begin{array}{l}2355 \mathrm{~kg} \\
\text { (c. } 1570 \mathrm{~kg} \\
\text { clean wool) }\end{array}$ & $\begin{array}{l}16186700 \mathrm{~m} \text { of yarn at } \\
404667 \text { hours (c. } 50583 \\
\text { working days at } 8 \mathrm{~h} / \text { day } \\
=138 \text { years/persons per } \\
\text { year) }\end{array}$ & 1570 \\
\hline & & & 7 & 10990 & $\begin{array}{l}3297 \mathrm{~kg} \\
\text { (c. } 2200 \mathrm{~kg} \text { of } \\
\text { clean wool) }\end{array}$ & $\begin{array}{l}22682000 \mathrm{~m} \text { of yarn at } \\
567050 \text { hours (c. } 70881 \\
\text { working days at } 8 \mathrm{~h} / \text { day } \\
=194 \text { years/persons per } \\
\text { year) }\end{array}$ & 2200 \\
\hline & \multirow[t]{3}{*}{$\begin{array}{l}\text { B) Sub- } \\
\text { sistence } \\
\text { agriculture } \\
\text { (c. } 130 \mathrm{ha} \text { ) }\end{array}$} & \multirow[t]{3}{*}{$\begin{array}{l}1614+65 \\
\text { of 'resting' } \\
\text { agricultural } \\
\text { land }=1679 \text { ha }\end{array}$} & 2 & 3358 & $\begin{array}{l}1007 \\
\text { (c. } 671 \mathrm{~kg} \text { of } \\
\text { clean wool) }\end{array}$ & $\begin{array}{l}6918010 \mathrm{~m} \text { of yarn at } \\
172950 \text { hours (c. } 21618 \\
\text { working days at } 8 \mathrm{~h} / \text { day } \\
=59 \text { years/persons per } \\
\text { year) }\end{array}$ & 671 \\
\hline & & & 5 & 8395 & $\begin{array}{l}\mathrm{kg} 2518.5 \\
\text { (c. } 1679 \mathrm{~kg} \text { of } \\
\text { clean wool) }\end{array}$ & $\begin{array}{l}17310490 \mathrm{~m} \text { of yarn and } \\
432762 \text { hours (c. } 54095 \\
\text { working days at } 8 \mathrm{~h} / \text { day } \\
=148 \text { years/persons per } \\
\text { year) }\end{array}$ & 1679 \\
\hline & & & 7 & 11753 & $\begin{array}{l}3526 \mathrm{~kg} \\
\text { (c. } 2350 \mathrm{~kg} \text { of } \\
\text { clean wool) }\end{array}$ & $\begin{array}{l}24228500 \mathrm{~m} \text { of yarn at } \\
605712 \text { hours (c. } 75714 \\
\text { working days at } 8 \mathrm{~h} / \text { day } \\
=207 \text { years/persons per } \\
\text { year) }\end{array}$ & 2350 \\
\hline
\end{tabular}

attempted to quantify the potential number of sheep managed by the site, and the wool yield that could be obtained each year. Data from the Bronze Age wool economies of the eastern Mediterranean as much as from modern guidelines for organic sheep farming show that husbandry practices are variable and dependent on both local regional environments and socio-political organizations of producing communities. Thus, the proposed quantifications have a strong hypothetical value.

The size of the local herds has been calculated using rather low stocking rates; however, even in the most unfavourable scenarios (see Tab. 3-5), Montale's surroundings could support a considerable number of sheep. In the same conservative scenarios, when applying the minimum wool yield possible (according to relevant Aegean Bronze Age texts), the total wool yield per year would nonetheless reach beyond any reasonable local consumption. The more favourable scenarios, probably still below the local maximum livestock farming capacity, would suggest that most of the community could be fully employed crafting between 0.5 and over 2 tons of wool per year.

The exceptional abundance of spindle whorls recovered at Montale has led to propose a community of practice model to explain the characteristics of the local engagement in wool economy ${ }^{113}$. Given the lack of clear

113 Sabatini et al. 2018a; Sabatini 2019. 
archaeological indicators for economic inequality, wool economy at the site is envisioned as a corporate investment where the whole community would participate in different ways. This model contrasts sharply with the state regulation known for the Aegean and Mesopotamian Bronze Age, suggesting a group-up line of economic development involving community specialization. Different from other Terramare villages of the Po plain, Montale and the settlements of Modena's alta pianura do not seem to radically change in size and structure with time $\mathrm{e}^{114}$. Maybe organized corporate investments and successful economic management could be at the core of such apparent political stability? The question is for future studies.

Acknowledgements: The project was supported by the Swedish Foundation for Humanities and Social Sciences under the Project Grant P15-0591:1 Bronze Age Wool Economy: production, trade, environment, herding and society. My deepest gratitude goes to Timothy Earle for his invaluable observations, and kind support. I am thankful to Karin M. Frei for sharing information from her analyses of the strontium isotopes and to the anonymous peer-reviewer for interesting comments and observations. Many thanks go to Jacopo De Grossi Mazzorin who facilitated the study of the animal remains from Montale and to Gianluca Pellacani who provided invaluable assistance throughout the project. Finally, this work would have not been possible without the generous support of Andrea Cardarelli.

\section{References}

Accorsi et al. 2009: C. A. Accorsi/M. Bandini Mazzanti/G. Bosi/ M. Marchesini/A. M. Mercuri/G. Trevisan, The archaeobotanical analyses. In: A. Cardarelli (ed.), Guide to the archaeological park and open-air museum Terramara Montale (Modena 2009) 64-67.

Albarella 2017: U. Albarella, Zooarchaeology in the twenty-first century: where we come from, where we are now, and where we are going. In: U. Albarella/M. Rizzetto/H. Russ/K. Vickers/ S. Viner-Daniel (eds), The Oxford Handbook of Zooarchaeology (Oxford 2017) 3-22.

-/Davis 2010: U. Albarella/S. Davis, The animal bones. In: A. Chapman (ed.), West Cotton, Raunds: A Study of Medieval Settlement Dynamics ad 450-1450 (Oxford 2010) 516-37.

Alderson 2016: L. Alderson, Sheep. In: V. Porter/L. Alderson/ S. J. G. Hall/D. P. Sponenberg (eds), Mason's World Encyclopedia of Livestock Breeds and Breeding, Volume II (Wallingford, Boston 2016) 723-956.

Andersson Strand 2014: E. Andersson Strand, Sheep, wool and textile production, an interdisciplinary approach on the

114 Cardarelli 2009c. complexity of wool working. In: C. Breniquet/C. Michel (eds), Wool Economy in the Ancient Near East and the Aegean. Ancient Textiles Series 17 (Oxford 2014) 41-51.

-/Cybulska 2012: E. Andersson Strand/M. Cybulska, Visualising Ancient Textiles - how to make a Textile Visible on the Basis of an Interpretation of an Ur III Text. In: M. L. Nosch/H. Koefoed/ E. Andersson Strand (eds.), Textile Production and Consumption in the ancient Near East (Oxford 2012) 113-127.

-/Nosch 2019: E. Andersson Strand/M. L. Nosch, The Wool Zone in Prehistory and Protohistory. In: S. Sabatini/S. Bergerbrant (eds), The Textile Revolution in Bronze Age Europe (Cambridge 2019) 15-38.

Armbuckle/Hammer 2018: B. S. Armbuckle/E. L. Hammer, The Rise of Pastoralism in the Ancient Near East. Journal Arch. Research 2018, 1-59, https://doi.org/10.1007/s10814-018-9124-8

Avondo et al. 2013: M. Avondo/P. Secchiari/L. M. Battaglini/ A. Bonanno/G. Pulina, Soil, Pasture and Animal Product Quality. Italian Journal of Agronomy 8/3, 2013. https://doi. org/10.4081/ija.2013.e19

Barber 1991: E. J. W. Barber, Prehistoric textiles: the development of cloth in the Neolithic and Bronze Ages with special references to the Aegean (Princeton 1991).

Bartosiewicz et al. 2013: L. Bartosiewicz/E. Gál/Z. E. Kovács, Domesticating Mathematics: Taxonomic Diversity in Archaeozoological Assemblages. In: A. Kulcsár/G. Kulcsár (eds), Moments in Time Papers Presented to Pál Raczky on His $60^{\text {th }}$ Birthday. Ősrégészeti Tanulmányok/Prehistoric Studies I, Eötvös Loránd University (Budapest 2013) 853-862.

Bazzanella 2012: M. Bazzanella, Italy: Neolithic and Bronze Age. In: M. Gleba/U. Mannering (eds), Textiles and textile production in Europe from prehistory to AD 400. Ancient Textiles Series 11 (Oxford 2012) 203-213.

Becker et al. 2016: C. Becker/N. Benecke/A. Grabundžija/ H.-C. Küchelmann/S. Pollock/W. Schier, The Textile Revolution. Research into the Origin and Spread of Wool Production between the Near East and Central Europe. ETopoi Journal for Ancient Studies Special 6, 2016, 102-151.

Belanová Štolcova/Grömer 2010: T. Belanová Štolcova/K. Grömer, Loom-weights, Spindles and Textiles - Textile Production in Central Europe from the Bronze and Iron Age. In: E. Andersson Strand/M. Gleba/U. Mannering/C. Munkholt/M. Ringgaard (eds), North European Symposium for Archaeological Textiles X. Ancient Textile Series 5 (Oxford 2010) 9-20.

Bender Jørgensen 1992: L. Bender Jørgensen, North European Textiles until AD 1000 (Aarhus 1992).

- 2012: L. Bender Jørgensen, The introduction of sails to Scandinavia: Raw materials, labour and land. In: R. Berge/ M. E. Jasinski/K. Sognnes (eds), N-TAG TEN. Proceedings of the $10^{\text {th }}$ Nordic TAG conference at Stiklestad, Norway 2009. BAR int. Series 2399 (Oxford 2012) 173-181.

- 2018: L. Bender Jørgensen, Textile Production. In: L. Bender Jørgensen/J. Sofaer/M. L. S. Sørensen (eds), Creativity in the Bronze Age: Understanding Innovation in Pottery, Textile, and Metalwork Production (Cambridge 2018) 67-73.

- 2013: L. Bender Jørgensen/K. Grömer, The archaeology of textiles - Recent advances and new methods. Godišnjak Hvratskog Restauratorskog Zavoda 3, 2013, 91-111.

-/Rast-Eicher 2015: L. Bender Jørgensen/A. Rast-Eicher, Searching for the earliest wools in Europe. In: K. Grömer/F. Pritchard 
(eds), Aspects of the Design, Production and Use of Textiles and Clothing from the Bronze Age to the Early Modern Era, NESAT XII. Archeolingua 33 (Budapest 2015) 67-72.

-/- 2018: L. Bender-Jørgensen/A. Rast-Eicher, Fibres for Bronze Age textiles. In: L. Bender Jørgensen/J. Sofaer/M.L.S. Sørensen (eds), Creativity in the Bronze Age: Understanding Innovation in Pottery, Textiles, and Metalwork Production (Cambridge 2018) 25-36.

Bendrey 2011: R. Bendrey, Some like it hot: environmental determinism and the pastoral economies of the later prehistoric Eurasian steppe, Pastoralism: Research, Policy and Practice 1.8, 2011. https://doi.org/10.1186/2041-7136-1-8

Benecke 1994: N. Benecke, Der Mensch und seine Haustiere: Die Geschichte einer jahrtausendealten Beziehung (Stuttgart 1994).

Bergerbrant 2018: S. Bergerbrant, Creativity and spindle whorls at the Bronze Age tell of Százhalombatta-Földvár, Hungary. In: L. Bender Jørgensen/J. Sofaer/M. L. S. Sørensen (eds), Creativity in the Bronze Age (Cambridge 2018) 91-98.

- 2019: S. Bergerbrant, Wool textiles in the Early Nordic Bronze Age: Local or Traded? In: S. Sabatini/S. Bergerbrant (eds), The Textile Revolution in Bronze Age Europe (Cambridge 2019) 255-273.

Bernabò Brea et al. 2007: M. Bernabò Brea/L. Bronzoni/ M. Cremaschi/S. Costa (eds), Gli scavi nella terramara Santa Rosa a Fodico di Poviglio (Poviglio 2007).

- 1997a: M. Bernabò Brea/A. Cardarelli/M. Cremaschi (eds), Le Terramare. La più antica civiltà padana (Milan 1997).

- 1997b: M. Bernabò Brea/A. Cardarelli/M. Cremaschi, Il crollo del sistema terramaricolo. In: M. Bernabò Brea/A. Cardarelli/ M. Cremaschi (eds), Le Terramare. La più antica civiltà padana (Milan 1997) 745-756.

-/Mutti 1994: M. Bernabò Brea/A. Mutti (eds), “Le Terremare si scavano per concimare i prati...”. La nascita dell'archeologia preistorica a Parma nella seconda metà dell'Ottocento (Parma 1994).

Biga 2014: M. G. Biga, Some aspects of the Wool Economy at Ebla. In: C. Breniquet/C. Michel (eds), Wool economy in the ancient Near East and the Aegean: From the beginnings of sheep husbandry to institutional textile industry (Oxford 2014) 139-150.

Blakesley/Buckley 2016: D. Blakesley/P. Buckley, Grassland Restoration and Management (Exeter 2016).

Boni 1882: C. Boni, La Terramara del Montale: scavo generale. Parte prima. Scavi dell'Ottobre, Novembre e Dicembre 1881. Relazione (Modena 1882).

- 1884: C. Boni, La Terramara del Montale. Scavo generale. Parte 2. Scavi del 1882-1883 (Modena 1884).

Bökönyi 1974: S. Bökönyi, History of domestic mammals in central and Eastern Europe (Budapest 1974).

Brandt 2014: L. $\emptyset$. Brandt, Species identification of skins and development of sheep wool: An interdisciplinary study combining textile research, archaeology, and biomolecular methods (Unpubl. PhD thesis, University of Copenhagen, Copenhagen 2014).

Breniquet/Michel 2014: C. Breniquet/C. Michel (eds), Wool economy in the ancient Near East and the Aegean: From the beginnings of sheep husbandry to institutional textile industry (Oxford 2014).
Broholm/Hald 1940: H. C. Broholm/M. Hald, Costumes of the Bronze Age in Denmark: Contributions to the Archaeology and Textilehistory of the Bronze Age (Copenhagen 1940).

Buckley et al. 2009: M. Buckley/M. Collins/J. Thomas-Oates/ J. C. Wilson, Species identification by analysis of bone collagen using matrix-assisted laser desorption/ionisation time-of-flight mass spectrometry. Rapid Communications in Mass Spectrometry 23, 2009, 3843-3854 doi: 10.1002/rcm.4316.

- 2010: M. Buckley/S. Whitcher Kansa/S. Howard/S. Campbell/ J. Thomas-Oates/M. Collins, Distinguishing between archaeological sheep and goat bones using a single collagen peptide. Journal Arch. Sci. 37, 2010, 13-20.

Campana et al. 2013: M. G. Campana/T. Robinson/P. F. Campos/ N. Tuross, Independent confirmation of a diagnostic sheep/ goat peptide sequence through DNA analysis and further exploration of its taxonomic utility within the Bovidae. Journal of Archaeological Science 40/2, 2013, 1421-1424.

Cardarelli 2006: A. Cardarelli, L'Appennino modenese nell'età del Bronzo. In: A. Cardarelli/L. Malnati (eds), Atlante dei beni archeologici della provincia di Modena. Volume II (Florence 2006) 40-68.

- 2009a: A. Cardarelli (ed.), Guide to the Archaeological Park and Open-Air Museum Terramara Montale (Modena 2009).

- 2009b: A. Cardarelli, The collapse of the Terramare culture and growth of new economic and social systems during the Late Bronze Age in Italy. Scienze dell'Antichità 15, 2009, 449-520.

- 2009c: A. Cardarelli Insediamenti dell'età del bronzo fra Secchia e Reno. Formazione, affermazione e collasso delle Terramare. In: A. Cardarelli/L. Malnati (eds), Atlante dei beni archeologici della provincia di Modena, Volume III (Florence 2009) 33-58.

- 2015: A. Cardarelli, Different forms of social inequality in Bronze Age Italy. Origini XXXVIII, 2, 2015, 151-200.

- et al. fothcoming: A. Cardarelli/G. Bosi/R. Rinaldi/U. Ucchesu/ G. Bacchetta, Vino o non vino? In Preistoria del cibo. L'alimentazione nella preistoria e nella protostoria. Atti della L Riunione Scientifica IIPP (Florence fothcoming).

-/Labate 2009a: A. Cardarelli/D. Labate, Ditch and Embankment. In: A. Cardarelli (ed.), Guide to the Archaeological Park and Open-Air Museum Terramara Montale (Modena 2009) 28-31.

- 2009b: A. Cardarelli/D. Labate The excavations 1996-2001. In: A. Cardarelli (ed.), Guide to the Archaeological Park and Open-Air Museum Terramara Montale (Modena 2009) 32-52.

Cavazzuti/Putzolu 2015: C. Cavazzuti/C Putzolu, Strategie di occupazione dell'Appennino emiliano durante l'Età del Bronzo. In: F. Cambi/G. De Venuto/R. Goffredo (eds), I pascoli, i campi, il mare. Paesaggi d'altura e di pianura in Italia dall'Età del Bronzo al Medioevo. Storia e Archeologia Globale 2 (Bari 2015) 51-71.

- et al. 2019: C. Cavazzuti/R. Skeates/A.R. Millard/G. Nowell/J. Peterkin/M. Bernabò Brea/A. Cardarelli/L. Salzani, Flows of people in villages and large centres in Bronze Age Italy through strontium and oxygen isotopes. PLoS ONE 14/1, 2019, e0209693. https://doi.org/10.1371/journal.pone.0209693

Cacho et al. 1995: O. J. Cacho/J. D. Finlayson/A. C. Bywater, A simulation Model of Grazing Sheep: II. Whole Farm Model, Agricultural Systems 48, 1995, 27-50.

CinBa database. Database of Bronze Age textiles in Europe. http//:cinba.net/outputs/databases/textiles/ 
Clutton-Brock et al. 1991: T. H. Clutton-Brock/O. F. Price/ S. D. Albon/P. A. Jewell, Persistent Instability and Population Regulation in Soay Sheep, Animal Ecology 60/2, 1991, 593-608.

Corti 2012: C. Corti, L'economia della lana a Mutina. In: M.S. Busana/P. Basso (eds), La lana nella Cisalpina romana. Economia e Società studi in onore di Stefania Pesavento Mattioli (Padua 2012) 213-229.

Costin 2013: C. L. Costin, Gender and textile production in prehistory. In: D. Bolger (ed.), A Companion to Gender Prehistory (Oxford 2013) 180-202.

Cremaschi et al. 2006: M. Cremaschi/C. Pizzi/V. Valsecchi, Management and land use in the terramare and a possible climatic co-factor in their abandonment: the case study of the terramara of Poviglio Santa Rosa (northern Italy). Quaternary International 151, 2006, 87-98.

- 2016: M. Cremaschi/A. M. Mercuri/P. Torri/A. Florenzano/C. Pizzi/ M. Marchesini/A. Zerboni, Climate change versus land management in the Po Plain (Northern Italy) during the Bronze Age: New insights from the VP/VG sequence of the Terramara Santa Rosa di Poviglio. Quaternary Science Reviews 136, 2016, 153-172.

De Grossi Mazzorin 2013: J. De Grossi Mazzorin, Considerazioni sullo sfruttamento animale in ambito terramaricolo. In: J. De Grossi Mazzorin/A. Curci/G. Giacobini (eds), Economia e ambiente nell'Italia padana dell'età del bronzo. Le indagini bioarcheologiche (Bari 2013) 257-263.

-/Ruggini 2009: J. De Grossi Mazzorin/C. Ruggini, The archaeozoological analysis. In: A. Cardarelli (ed.), Guide to the Archaeological Park and Open-Air Museum Terramara Montale (Modena 2009) 68-69.

Del Freo et al. 2010: M. Del Freo/M. L. Nosch/F. Rougemont, The terminology of Textiles in the Linear B tablets, including some considerations on Linear A Logograms and Abbreviations. In: C. Michel/M. L. Nosch (eds), in Textile Terminologies in the Ancient Near East and Mediterranean from the Third to the First Millennia BC. Ancient Textiles Series 8 (Oxford 2010) 338-373.

Earle/Kristiansen 2010: T. Earle/K. Kristiansen, Organizing Bronze Age Societies (Cambridge 2010).

Elias/Tischew 2016: D. Elias/S. Tischew, Goat pasturing A biological solution to counteract shrub encroachment on abandoned dry grasslands in Central Europe? Agriculture, Ecosystems \& Environment 234, 2016, 98-106.

Esmail 1991: S. H. M. Esmail, Multispecies grazing by cattle and sheep. Rangelands 13/1,1991, 35-37.

Eurostat LSU https://ec.europa.eu/eurostat/statistics-explained/ index.php/Glossary:Livestock_unit_(LSU)

Farello 2011: P. Farello, La fauna della Terramara. In: P. Desantis/ M. Marchesini/S. Marvelli (eds), Anzola al tempo delle Terramare (San Giovanni in Persiceto 2011) 46-48.

Ferrari et al. 2018: P. Ferrari/M. Bernabò Brea/L. Bronzoni/ C. Basile/P. A. E. Bianchi/F. Guarisco, L'area abitativa della prima fase nella terramara di Forno del Gallo a Beneceto (Parma). In: M. Bernabò Brea (ed.), Preistoria e Protostoria dell'Emilia Romagna II (Florence 2018) 93-100.

Firth 2014: R. Firth, Considering the population Statistics of the sheep listed in the East-West corridor Archive at Knossos. In: D. Nakassis/J. Gulizio/A. James (eds), KE-RA-ME-JA Studies presented to Cynthia W. Shelmerdine (Philadelphia 2014) 293-304.
Florenzano et al. 2015: A. Florenzano/M. Marignani/L. Rosati/ S. Fascetti/A. M. Mercuri, Are Cichorieae an indicator of open habitats and pastoralism in current and past vegetation studies? Plant Biosystems - An International Journal Dealing with all Aspects of Plant Biology 149/1, 2015, 154-165,

Foster 2014: B. R. Foster, Wool in the economy of Sargonic Mesopotamia. In: C. Breniquet/C. Michel (eds), Wool Economy in the Ancient Near East and the Aegean. Ancient Textiles Series 17 (Oxford) 115-123.

Frangipane et al. 2009: M. Frangipane/E. Andersson Strand/ R. Laurito/S. Möller-Wiering/M. L. Nosch/A. Rast-Eicher, Arslantepe, Malatya (Turkey): Textiles, tools and imprints of fabrics from the $4^{\text {th }}$ to the $2^{\text {nd }}$ millennium BCE. Paleorient 53/1, 2009, 5-29.

Frei/Frei 2011: K. M. Frei/R. Frei, The geographic distribution of strontium isotopes in Danish surface waters - A base for provenance studies in archaeology, hydrology and agriculture, Applied Geochemistry 26, 2011, 326-340.

Frei et al. 2015: K. M. Frei/U. Mannering/K. Kristiansen/ M. E. Allentoft/A. S. Wilson/S. Tridico/M. L. Nosch/ E. Willerslev/L. Clarke/R. Frei, Tracing the dynamic life story of a Bronze Age Female. Scientific Reports 5, 2015, e10431.

- 2017: K. M. Frei/U. Mannering/I. Vanden Berghe/K. Kristiansen, Bronze Age wool: provenance and dye investigations of Danish textiles. Antiquity 91/357, 2017, 640-654.

Gillis et al. 2011: R. Gillis/L. Chaix/J. D. Vigne, An assessment of morphological criteria for discriminating sheep and goat mandibles on a large prehistoric archaeological assemblage (Kerma, Sudan). Journal of Archaeological Science 38, 2011, 2324-2339.

Gleba 2008: M. Gleba, Textile Production in Pre-roman Italy, Ancient Textile Series 4 (Oxford 2008).

- 2012: M. Gleba, From textiles to sheep: investigating wool fibre development in pre-Roman Italy using scanning electron microscopy (SEM). Journal of Archaeological Science 39, 2012, 3643-3661.

-/Mannering 2012: M. Gleba/U. Mannering (eds), Textiles and Textile Production in Europe from Prehistory to AD 400, Ancient Textiles Series 11 (Oxford 2012).

Grace et al. 2018: C. Grace/T. M. Boland/H. Sheridan/S. Lott/ E. Brennan/R. Fritch/M. B. Lynch, The effect of increasing pasture species on herbage production, chemical composition and utilization under intensive sheep grazing. Grass and Forage Science 73/4, 2018, 852-864.

Gregg 1988: S. A. Gregg, Foragers and Farmers. Population Interaction and Agricultural Expansion in Prehistoric Europe (Chicago/London 1988).

Green 1980: M. W. Green, Animal Husbandry at Uruk in the Archaic Period, Journal of Near Eastern Studies 39, 1980, 1-35.

Greenfield 2005: H. J. Greenfield, A reconsideration of the secondary products revolution in southeastern Europe, on the origins and use of domesticated animals for milk, wool, and traction in the central Balkans. In: J. Mulville/A. Outram (eds), Zooarchaeology of Fats, Oils, Milk and Dairying. Proceedings of the $9^{\text {th }}$ Conference of the International Council of Archaeozoology, Durham, August 2002 (Oxford 2005) 14-31.

- 2014: H. J. Greenfield, Animal Secondary products: Archaeological Perspective on Domestic Animal Exploitation in the Neolithic and Bronze Age (Oxford 2014). 
- 2017: H. J. Greenfield, The Spread of Productive and Technological Innovations in Europe and the Near East: An Integrated Zooarchaeological Perspective on Secondary Animal Products and Bronze Utilitarian Metallurgy. In: P. W. Stockhammer/ J. Maran (eds), Appropriating Innovations Entangled Knowledge in Eurasia, 5000-1500 BCE (Oxford 2017) 50-68.

Grömer 2013: K. Grömer, Discovering the people behind the textiles: Iron Age textile producers and their products in Austria. In: M. Gleba/J. Pásztókai-Szeöke (eds), Making Textiles in Pre-Roman and Roman Times, People Places, Identities, Ancient Textiles Series 13 (Oxford 2013) 30-59.

- 2016: K. Grömer, The Art of Prehistoric Textile Making - The Development of craft Traditions and Clothing in Central Europe. Veröffentlichungen der Prähistorischen Abteilung 5 (Vienna 2016).

- et al. 2013: K. Grömer/A. Kern/H. Reschreiter/H. Rösel-Mautendorfer, Textiles from Hallstatt Weaving Culture in Bronze Age and Iron Age Salt Mines. Archeolingua 29 (Budapest 2013).

- et al. 2018: K. Grömer/L. Bender Jørgensen/M. Marić Baković, Missing link: an early wool textile from Pustopolje in Bosnien Herzegovina. Antiquity 93/362, 2018, 351-367.

-/Saliari 2018: K. Grömer/K. Saliari, Dressing Central European prehistory - the sheep's contribution. An interdisciplinary study about archaeological textile finds and archaeozoology. Annalen des Naturhistorischen Museums in Wien, 120, 2018, 127-156.

Hadjigeorgiou et al. 2005: I. Hadjigeorgiou/K. Osoro/J. P. Fragoso de Almeida/G. Molle, Southern European grazing lands: Production, environmental and landscape management aspects. Livestock Production Science 96, 2005, 51-59.

Halstead 1998: P. Halstead, Mortality Models and Milking: Problems of Uniformitarism Optimality and Equifinality Reconsidered. Anthopozoologica, 27, 1998, 3-20.

- et al. 2002:-/P. Collins/V. Issakidou, Sorting sheep from the goats: morphological distinction between the mandibles and mandibular teeth between of adult Ovis and Capra. Journal of Archaeological Science 29, 2002, 545-553.

Harding 1995: A. Harding, The Finds from Pustopolje Tumulus 16 and Their European Context. Eirene XXXI, 1995, 112-119.

-/Fokkens 2013: A. Harding/H. Fokkens (eds), The Oxford Handbook of European Bronze Age (Oxford 2013).

Killen 1964: J. T. Killen, The Wool Industry in Crete in the Late Bronze Age. The Annual of the British School at Athens 59, 1964, 1-15.

- 2007: -, Cloth Production in Late Bronze Age Greece: the Documentary Evidence. In: C. Gillis/M.L. Nosch (eds), Ancient Textiles, production, craft and society (Oxford 2007) 50-59.

Kintzel 2010: U Kintzel, How to get started with sheep. Cornell Small Farms Program, Cornell University https://smallfarms.cornell. edu/2010/07/04/how-to-get-started-with-sheep/

Kristiansen 2016: K. Kristiansen, Interpreting Bronze Age Trade and Migration, in Human Mobility and Technological Transfer. In: E. Kiratzi/C. Knappett (eds), The Prehistoric Mediterranean (Cambridge 2016) 154-180.

Kneisel/Schaefer 2019: J. Kneisel/S. Schaefer, Loom Weights in Bronze Age Central Europe. In: S. Sabatini/S. Bergerbrant (eds), The Textile Revolution in Bronze Age Europe (Cambridge 2019) 80-116.

Labate 2011: D. Labate, L'agro centuriato di Mutina: l'insediamento romano nell'area di Baggiovara. In: D. Labate/D. Locatelli (eds),
L'insediamento etrusco e romano di Baggiovara (MO). Quaderni di archeologia dell'Emilia Romagna 27 (Florence 2011) 21-34.

Mannering et al. 2012: U. Mannering/M. Gleba/M. Bloch Hansen, Denmark. In: M. Gleba/U. Mannering (eds), Textiles and Textile Production in Europe: From Prehistory to AD 400. Ancient Textiles Series 11 (Oxford 2012) 91-118.

Marić Baković/Car 2014: M. Marić Baković/G. Car, Konzervatorsko-restauratorski radovi I rezultati najnovijih analiza na tekstilnome plaštu is prapovijesnoga zemljanog tumula Br. 16 , Pustopolje, Kupres, Cleuna, 1, 2014, 30-47.

Matoïan/Vita 2014: V. Matoïan/J.-P. Vita, Wool production and economy at Ugarit. In: C. Breniquet/C. Michel (eds), Wool economy in the ancient Near East and the Aegean: From the beginnings of sheep husbandry to institutional textile industry (Oxford 2014) 310-339.

McCorriston 1997: J. McCorriston, The fiber revolution. Textile extensification, alienation and social stratification in Ancient Mesopotamia. Current Anthropology 38/4, 1997, 517-549.

Mercuri et al. 2006: A. M. Mercuri/C. A. Accorsi/M. Bandini Mazzanti/G. Bosi/A. Cardarelli/D. Labate/M. Marchesini/ G. Trevisan, Economy and environment of Bronze Age settlements - Terramaras - on the Po Plain (Northern Italy): first results from the archaeobotanical research at the Terramara di Montale. Vegetation History and Archaeobotany 16, 2006, 43-60.

Michel 2014: C. Michel, Wool Trade in Upper Mesopotamia and Syria According to Old Babylonian and Old Assyrian Texts. In: C. Breniquet/C. Michel (eds), Wool economy in the ancient Near East and the Aegean: From the beginnings of sheep husbandry to institutional textile industry. (Oxford 2014) 232-254.

-/Nosch 2010: C. Michel/M. L. Nosch (eds), Textile Terminologies in the Ancient Near East and Mediterranean from the Third to the First Millennia BC. Ancient Textiles Series 8 (Oxford 2010).

Milligan et al. 2016: G. Milligan/R. J. Rose/R. H. Marrs, Winners and losers in a long-term study of vegetation change at Moor House NNR: Effects of sheep-grazing and its removal on British upland vegetation. Ecological Indicators 68, 2016, 89-101.

Molle et al. 2001: G. Molle/M. Decandia/S. Ligios/N. Fois/M. Sitzia, Il pascolamento e il carico animale. In G. Pulina (ed.), L'alimentazione degli ovini da latte (Bologna 2001) 275-304.

- 2004: G. Molle/M. Decandia/S. Ligios/N. Fois/T. T. Treacher/ M. Sitzia, Grazing management and stocking rate with particular reference to Mediterranean environments. In: G. Pulina/R. Bencini (eds), Dairy Sheep Nutrition (Wallingford, Cambridge 2004) 191-211.

Nosch 2014: M. L. Nosch, The Aegean wool economies of the Bronze Age. Textile Society of America Symposium Proceedings 900 (http://digitalcommons.unl.edu/tsaconf/900).

- 2015: -, The Wool Age: Traditions and Innovations in Textile Production, Consumption and Administration in the Late Bronze Age Aegean. In: J. Weilhartner/F. Ruppenstein (eds), Tradition and Innovation in the Mycenaean Palatial Polities (Vienna 2015) 167-201.

Pacciarelli 2016: M. Pacciarelli, The earliest processes towards city-states, political power and social stratification in the middle tyrrhenian Italy. Origini XXXIX/1, 2016, 165-202.

Payne 1973: S. Payne, Kill-off patterns in sheep and goats: the mandibles from Aşvan Kale. Anatolian Studies 23, 1973, 281-303. 
Peres 2010: T. M. Peres, Methodological Issues in Zooarchaeology. In: A. M. Van Derwarker/T. M. Peres (eds), Integrating Zooarchaeology and Paleoethnobotany: A Consideration of Issues, Methods, and Cases (New York 2010) 15-36.

Pipes et al. 2014: M. L. Pipes/J. Kuuk/S. Milisauskas, Asseing the archaeological data for wool-bearing sheep during the Middle to Late Neolithic at Bronocice, Poland. In: H. Greenfiled (ed.), Animal Secondary products: Archaeological Perspective on Domestic Animal Exploitation in the Neolithic and Bronze Age (Oxford 2014) 80-102.

Randall 2010: C. E. Randall, Livestock and landscape: exploring animal exploitation in later prehistory in the South West of Britain (Unpubl. Doctoral Thesis, Bournemouth University 2010).

Rast-Eicher 2003: A. Rast-Eicher, Determinazione delle fibre. In: M. Bazzanella/A. Mayr/L. Moser/A. Rast-Eicher (eds), Textiles. Intrecci e tessuti dalla preistoria europea (Trento 2003) 55-60.

Riedel 1996: A. Riedel, Archaeozoological investigations in North-eastern Italy: the exploitation of animals since the Neolithic. Preistoria Alpina 30, 1994, 43-94.

Rougemont 2014: F. Rougemont, Sheep Breeding and Wool Exploitation in the Mycenaean Written Documents. In: C. Breniquet/C. Michel (eds), Wool Economy in the Ancient Near East and the Aegean: From the Beginnings of Sheep Husbandry to Institutional Textile Industry. Ancient Textiles 17 (Oxford 2014) 340-370.

Ryder 1983: M. L. Ryder, Sheep and Man (London 1983).

Sabatini 2018: S. Sabatini, Wool Economy during the European Bronze Age. Światowit LVI, 2017, 43-55.

- 2019: -, Weaving in Bronze Age Italy: The Case of the Terramare Settlement at Montale. In: S. Sabatini/S. Bergerbrant (eds), The Textile Revolution in Bronze Age Europe (Cambridge 2019) 39-79.

-/Bergerbrant 2019: -/S. Bergerbrant, Textile Production and Specialization in Bronze Age Europe. In: S. Sabatini/ S. Bergerbrant (eds), The Textile Revolution in Bronze Age Europe (Cambridge 2019) 1-14.

- et al. 2018a: -/T. Earle/A. Cardarelli, Bronze Age textile and wool economy: The case of the Terramare site of Montale, Italy. Proceedings of the Prehistoric Society 84, 2018, 359-385.

- et al. 2018b: -/K. M. Frei/J. De Grossi Mazzorin/A. Cardarelli, Bronze Age wool economy at Montale (MO, Italy): production, husbandry and society, Unpublished Poster at the $9^{\text {th }}$ AIAZ national conference, 28.-30. November 2018, Ravenna, Italy.

- et al. 2019: -/S. Bergerbrant/L. Ø. Brandt/A. Margaryan/ M. E. Allentoft, Approaching sheep herds origin and the emergence of wool economy in continental Europe during the Bronze Age. Anthropological and Archaeological Sciences 11/9, 2019, 4909-4925, doi: https://doi.org/10.1007/s12520-01900856-x

- forthcoming: -/K. M. Frei/J. De Grossi Mazzorin/A. Cardarelli, Montale Pastoral Economy and the Results of Strontium Isotope Analyses.
Saltini 1997: A. Saltini, L'estrazione della “terra mara” un'industria rurale nell'Emilia dell'Ottocento. In: M. Bernabò Brea/ A. Cardarelli/M. Cremaschi (eds), Le Terramare. La più antica civiltà padana (Milan 1997) 187-195.

Salvagno/Albarella 2017: L. Salvagno/U. Albarella, A morphometric system to distinguish sheep and goat postcranial bones. PLoS ONE 12/6, 2017, 1-37.

Schmölcke et al. 2018: U. Schmölcke/D. Gross/E. A. Nikulina, The history of sheep husbandry in Austria from the Neolithic to the Roman Period. Annalen des Naturhistorischen Museums in Wien, Serie A, 120, 2018, 101-126.

Sieff 1997: D. F. Sieff, Herding Strategies of the Datoga Pastoralists of Tanzania: Is Household Labor a Limiting Factor. Human Ecology 25/4, 1997, 519-544.

Sinding et al. 2015: M.-H.S. Sinding/J. Arneborg/G. Nyegaard/ M. T. P. Gilbert, Ancient DNA unravels the truth behind the controversial GUS Greenlandic Norse fur samples: the bison was a horse, and the muskox and bears were goats. Journal of Archaeological Science 53, 2015, 297-303.

Sofaer et al. 2013: J. Sofaer/L. Bender Jørgensen/A. Choyke, Craft production: ceramics, textiles and bone. In: A. Harding/ H. Fokkens (eds), The Oxford Handbook of European Bronze Age (Oxford 2013) 469-491.

Superchi et al. 2007: P. Superchi/C. Baratta/V. Beretti/A. Sabbioni, Caratteristiche nutritive di prati-pascoli dell'appennino parmense. Nutritional value of natural pastures in parmesan apennines. Annali della Facoltà di Medicina Veterinaria di Parma XXVII, 2007, 189-198.

Umberger 2009: S. H. Umberger, Sheep Grazing Management. Virginia Cooperative Extension, publication 410-366. https://vtechworks.lib.vt.edu/bitstream/ handle/10919/48478/410-366_pdf.pdf?sequence=1

Vizioli 2015: V. Vizioli, Norme ed adempimenti di legge per la produzione zootenica secondo il metodo biologico. Progetto INFOPACK https://www.aiablombardia.it/zootecnia-biologicaprincipi-generali-7/

Vretemark 2010: M. Vretemark, Subsistence strategies. In: T. Earle/ K. Kristiansen (eds), Organizing Bronze Age Societies; the Mediterranean, Central Europe, and Scandinavia Compared (Cambridge 2010) 155-184.

Walker 1994: J. W. Walker, Multispecies Grazing: The Ecological Advantage. Sheep research Journal 1994, 52-64.

Waetzoldt 1972: H. Waetzoldt, Untersuchungen zur neusumerischen Textilindustrie (Rome 1972).

Wisti Lassen 2010: A. Wisti Lassen, The trade on wool in old Assyrian Anatolia. Jaarbericht Ex Oriente Lux 42, 2010, 159-179.

Wright 2013: R. P. Wright, Sumerian and Akkadian industries: Crafting textiles. In: H. Crawford (ed.), The Sumerian World (London 2013) 395-418. 